\section{Contabilidade tributária: Estudo bibliométrico da área contábil entre o período de 2010 a 2020.}

\author{
Marcelo Rabelo Henrique \\ UNIFESP - Universidade Federal de São Paulo \\ mrhenique@unifesp.br \\ Jéssica Medeiros da Silva \\ UNIFESP - Universidade Federal de São Paulo \\ jessica.medeiros@unifesp.com \\ Antônio Saporito \\ UNIFESP - Universidade Federal de São Paulo \\ saporito@unifesp.br \\ Sandro Braz Silva \\ UNIFESP - Universidade Federal de São Paulo \\ sandro.braz@unifesp.br
}

\section{Resumo}

O presente estudo tem como objetivo investigar os fatores determinantes do excesso de confiança em estudantes de Ciências Contábeis Este estudo objetivou averiguar como se caracteriza a produção científica sobre "Contabilidade Tributária" nas revistas Contabilidade Vista \& Revista e na Revista Brasileira de Gestão e Negócios - RBGN entre o período de 2010 a 2020. A escolha das duas revistas cientificas teve por base estarem no grupo das oito revistas brasileiras com melhor QUALIS, A2, e se distinguirem, uma da outra, em termos de categoria administrativa e localização das instituições de ensino a que estão ligadas. As observações foram feitas por longo período para que eventuais mudanças ao longo do tempo pudessem ser notadas. Para desempenhar o objetivo exposto, adotou-se a abordagem bibliométrica, com mensuração bibliométrica e metodologias baseadas nas Leis de Bradford (produtividade de periódicos) e Lotka (produtividade dos autores) que visa encontrar a frequência de determinados termos em um artigo científico. Os resultados evidenciaram que no acumulado de todo o período as publicações referentes a contabilidade tributária representaram $5 \%$ do total de artigos publicados nas duas revistas, mas que a partir de 2015 essa relação é crescente e atingiu seu ponto de máximo em 2018 com 10\% de participação. Constatou-se que a quase totalidade das pesquisas são empíricas, uma vez que apenas $4 \%$ são trabalhos teóricos e que para sua elaboração tiveram outros artigos científicos como principal fonte de referências. Além disso foi observado que cerca de três quartos dos autores têm titulação acadêmica de doutor, quase metade dos artigos é escrita por dois autores e $54 \%$ deles está vinculado a instituições da região sudeste. Entre os autores dos 65 artigos examinados apenas um autor contribuiu com dois artigos e todos os demais participaram com um só, de modo que não houve um grupo que se destacasse. Pôde-se concluir com base na amostra especificada que a produção científica de alto nível em contabilidade tributária é modesta, mas vem crescendo nos últimos cinco anos, é predominantemente empírica, executada na maioria das vezes por duplas de pesquisadores, doutores e sediados na região sudeste, sendo que não há autores que se destaquem por quantidade expressiva de publicações. Sugere-se para pesquisas futuras a manutenção do mesmo período de pesquisa e revistas alterando a área pesquisada ou ainda manter a área de contabilidade tributária como foco da pesquisa e ampliar a quantidade de revistas.

Palavras-chave: Contabilidade Tributária. Bibliometria. Planejamento Tributário.

ISSN: 1984-6266

Recebimento:

07/11/2020

Aprovação:

08/01/2021

Editor responsável pela

aprovação do artigo:

Dra. Luciana Klein

Editor responsável pela edição do artigo:

Dra. Luciana Klein

Avaliado pelo sistema:

Double Blind Review

A reprodução dos artigos, total ou parcial, pode ser feita desde que citada a fonte.

PROGRAMA DE PÓS-GRADUAÇÃO EM GONTABILIDADE MESTRADO E DOUTORADO

DOI:

http://dx.doi.org/10.5380/rcc.v12i3.77754 


\title{
TAX ACCOUNTING: BIBLIOMETRIC STUDY OF THE ACCOUNTING AREA BETWEEN THE PERIOD 2010 TO 2020
}

\begin{abstract}
This study aimed to find out how the scientific production on "Tax Accounting" is characterized in the magazines Contabilidade Vista \& Revista and in the Revista Brasileira de Gestão e Negócios - RBGN between the period 2010 to 2020. The choice of the two scientific journals was based on be in the group of eight Brazilian magazines with the best QUALIS, A2, and distinguish themselves from each other in terms of administrative category and location of the educational institutions to which they are linked. The observations were made for a long period so that eventual changes over time could be noticed. To carry out the exposed objective, the bibliometric approach was adopted, with bibliometric measurement and methodologies based on the Laws of Bradford (productivity of journals) and Lotka (productivity of authors) which aims to find the frequency of certain terms in a scientific article. The results showed that in the accumulated of the whole period, publications referring to tax accounting represented $5 \%$ of the total articles published in the two magazines, but that from 2015 this relationship is growing and reached its peak in 2018 with $10 \%$ of participation. It was found that almost all the researches are empirical, since only $4 \%$ are theoretical works and for their elaboration they had other scientific articles as the main source of references. In addition, it was observed that about three quarters of the authors have an academic degree as a doctor, almost half of the articles are written by two authors and $54 \%$ of them are linked to institutions in the southeast region. Among the authors of the 65 articles examined, only one author contributed two articles and all the others participated with only one, so that there was no group that stood out. It was possible to conclude based on the specified sample that high-level scientific production in tax accounting is modest, but has been growing in the last five years, it is predominantly empirical, performed in most cases by pairs of researchers, doctors and headquartered in the southeast region, and there are no authors that stand out for a significant amount of publications. It is suggested for future research to maintain the same period of research and journals, changing the researched area or still keep the area of tax accounting as the focus of the research and increase the number of journals.
\end{abstract}

Keywords: Tax Accounting. Bibliometric. Tax Planning.

\section{Introduction}

To understand the scope of this study, it is necessary to resume some primordial concepts. According to Neves and Viceconti (2017) accounting is a science that has developed its own methodology with the purpose of controlling the assets of entities, determining their results, as well as providing reliable information to users who have an interest in the accounting and financial statements of entities.

Having as its primary function to evidence the accounting information of the entities in a clear and reliable way, accounting has in the provision of such information a fundamental role. This is because the information is necessary for the decision made by the administrators of an entity, as well as by other users who make use of such demos.

The demonstrations should be based on ethical principles conveying credibility in the situations reported. Therefore, the accounting professional must be attentive, to produce a correct and flawless analysis, because a small inaccuracy in accounting, may cause a great loss, consequently, the principles of ethics in the daily acts of the accounting profession are fundamental. 
The accounting area has already experienced several changes, such as requirements of international accounting standards for many companies since 2008 in Brazil. Associated with this, there were also specific laws, in the tax field, to contemplate such changes. This scenario, therefore, requires the accounting professionals attitudes for the continuous improvement of theories and methods of accounting and taxation, in order to place themselves prominently in the current labor market.

One of the ways to update yourself professionally in a given area of knowledge is through the scientific work generated. Thus, having available a set of articles specifically focused on the particular area of Accounting, such as Tax Accounting, could facilitate the work of professionals interested in the subject.

Bibliometric is a quantitative and statistical technique for measuring the indices of production and dissemination of scientific knowledge that emerged at the beginning of the century, resulting from the need for study and evaluation of scientific production and communication activities.

Defined main objective of this study, it was stipulated during the development to meet the following specific objectives:

(i) to identify the types of the selected researches;

(ii) identify the number of authors per article;

(iii) identify the authors, titles and regions of the country to which they belong and,

(iv) identify the most used type of reference.

To verify defined theme, tax accounting, is addressed in the academic environment, it was necessary to choose journals that refer to the accounting area. Therefore, the selected journals have as their main theme, topics related to accounting and administration, making it possible to comply with a more appropriate analysis.

The bibliometric approach was based on two journals: Vista \& Journal Accounting of the Federal University of Minas Gerais (UFMG) and the Brazilian Journal of Business Management - RBGN of the Álvares Penteado School of Commerce Foundation (FECAP) of São Paulo. These journals were chosen because they were qualified among the best publications and because they belong to institutions of different administrative categories and geographical locations.

The division of the present article was arranged in five fragments, the first being the introduction, in the second section, there is a review of the used literature; in the third, the methodology applied in conducting the research; in the fourth division the results; and on the fifth the conclusion of the study.

\section{Literature Revision}

To carry out the present work, it is necessary to review concepts extremely relevant to the research theme, including the objectives that this research area has. For this, a bibliographical research was carried out mainly related to accounting and tax planning, tax avoidance and evasion and bibliometry, using prominent authors in these subjects. In addition, considering the evolution of the literature over the years, it is fundamental to discuss and understand the aspects that will be evidenced in the results.

\subsection{Tax Accouting: Concepts and objectives}

Tax accounting in Brazil has been maintained within the curricula of business courses in the form of tax or customs legislation since its emergence in the 19th century, according to Soares (2011). When verifying the literature on accounting curricula, tax accounting topics taught in other disciplines Theóphilo (2000) were noticed, in which tax contents taught in the accounting theory discipline were perceived, for example. 
According to Carneiro (2008) currently, accounting courses have specific discipline on tax accounting. The Federal Accounting Council (CFC) suggests, through its "National Content Proposal for the Undergraduate Accounting Course", that the course curriculum has the offer of the disciplines "Tax Law and Legislation" and "Tax Planning and Accounting".

ludícibus, Martins and Gelbcke (2007) state that Accounting is an "information and evaluation system, designed to provide its users with demonstrations and analyzes of an economic, financial, physical and productivity nature, in relation to the entity, object of accounting".

For Fabretti (2006) tax accounting is "the branch of accounting that aims to apply, in practice, basic concepts, principles and norms of Accounting and tax legislation, simultaneously and appropriately". Also on the subject, Oliveira (2006) conceptualize tax accounting as "the accounting branch responsible for the management of taxes in the most varied operations carried out by a company, or group of companies, adapting to the day-today business tax obligations, so as not to expose the entity to possible tax and legal sanctions".

It is from these concepts, proposed by Fabretti (2006), Oliveira (2006), ludícibus, Martins and Gelbcke (2007) and Fabretti (2009), that this research was delimited within the scope of Accounting and excluding the area of Law. Therefore, theoretical and legal discussions on the most diverse aspects of national and international tax legislation, which take place within the scope of law, are not addressed in this research.

Also due to the complexity of the Brazilian tax system, taxpayers face enormous difficulties in fulfilling their main and ancillary obligations. In most cases, it is due to inadequate choice of taxation system that leads to debts with tax authorities. They still come up with market disloyalty on the part of competitors make use of illegal methods and snooze taxes.

\subsection{Tax Planning}

Tax planning is a valuable tool for companies, which, through its thorough study, makes it possible to choose the taxation system that best suits their reality (Fabretti, 2006; Formigoni, 2008). The important thing is that companies carry out tax planning regardless of their activities to adapt to their economic conditions so that they can benefit from reducing the tax burden. A well-designed tax planning assists in tax management, guides the company and reduces the impact of taxation legally and in accordance with the rules and regulations. It is a preventive activity and can be used as a decision-making activity. The plan is to select a legal tax system option that can bring better results to the organization (Lima, Duarte, 2017; Paula, 2018)

Generally, it is the accounting professionals who prepare this plan and assist in making decisions about the impact of the tax burden on the company's activities. Fabretti (2009) and Da Silva (2019), stated that, once a taxation plan was formulated and defined to orient economic activities, the next step was taken, namely tax management: management and issuing of documents, business and taxation, accounting and tax bookkeeping, Determine the tax payable, control the various payment terms and provide dozens of information required by federal, state and municipal tax authorities.

No one is obliged to choose between the various legally possible ways of analyzing the amounts of taxes to be collected that is not the most convenient. The tax legislation allows that, when there is more than one legally valid way for a tax obligation to be fulfilled as well as the calculation of its value, the taxpayer chooses the most favorable option (Silva, Coutinho, 2019).

Business management designed to protect industrial, commercial and service operations necessarily needs to understand the tax obligations and charges contained in each legally accepted alternative, so that they can be compared and the one that contributes to reducing or delaying the tax burden is chosen (Borges, 2002; Silva, Coutinho, 2019). 
For the realization of an effective tax planning it is essential that all taxes levied in the company's operations are considered and an individual assessment of the taxes is made in order to obtain benefits resulting from the reduction of the amount payable or the time to comply with the tax obligation.

To achieve an effective legal tax savings, it is necessary to integrate all departments of the company. Therefore, in case, in the event that decisions are made with the knowledge of people who are important to business success, it is essential to form an internal planning committee, with the consequent participation of these people. (Oliveira, 2014).

Tax planning is essential to entities and is justified by the fact that all taxpayers have the right to do their business without burdening themselves too much with taxes, in order to minimize the requirements determined by the legislation.

\subsection{Fiscal Elision}

It is a legal means to obtain a lower tax burden, through a good interpretation of tax legislation, where legal means are sought, whether foreseen or not, to the principles of law within the laws of each tax. Tax avoidance must be analyzed by each company as a lawful way to reduce its burden and increase its profit.

Tax avoidance consists in the performance of legal and ethical procedures, before the occurrence of taxable facts, to reduce, eliminate or postpone the framework of tax obligations, thus reflecting the legitimacy of tax planning. Due to the existence of gaps in tax legislation, opportunities for tax avoidance arose (Rezende, Pereira, Alencar, 2010).

Therefore, tax avoidance is an action that has as its premise the full compliance of legislation to avoid the occurrence of taxable incidents. This is a tax plan to save taxes (Higuchi, Higuchi, 2005; Rezende, Pereira, Alencar, 2010).

Based on the applied concepts, tax avoidance is totally linked to tax planning, because, in order to be effective in tax planning, one must follow according to what is provided for in the law of each tax and obtain legally a means of save taxes.

\subsection{Tax Evasion}

Tax evasion is unlawful or, at least, an administrative offense. It consists of non-payment of taxes, even when the taxable event has already been verified. Tools that directly violate tax law or regulation are used.

Tax evasion includes any illegal deliberate and spontaneous measures taken by taxpayers to prevent, eliminate, reduce or delay the payment of the tax due, which is not compatible with legal tax planning in any case (Zanluca, 2018).

Doctrine and jurisprudence conceptualize tax evasion as a violation of the law, with the aim of not paying taxes or paying fees or reducing taxable incidents. In tax evasion, there are always analog or hidden numbers (Higuchi, Higuchi, 2005; Zanluca, 2018).

Evasion allows for the occurrence of the taxable event, however, it seeks ways to falsify or omit information in order to avoid or reduce the tax incidence.

\subsection{Bibliometry}


In Brazil, the framework of the spread of bibliometric refers to the 1970s, with studies conducted at the Brazilian Institute of Bibliography and Documentation (IBBD), currently known as the Brazilian Institute of Scientific and Technological Information, IBICT. Originally known as "statistical bibliography", bibliometry turned to the measurement of books, aiming to quantify editions and copies, number of words, physical space occupied in libraries, among others. Gradually, it began to analyze bibliographic productions of other formats, such as journals and scientific articles, also beginning to understand the study of citations and the productivity of authors, worrying - always with the search for immediate practical benefits and the analysis of scientific production. (Araújo, 2006; Almeida, Machado, Machado, Zanolla, 2017; Anjos, Pederneiras, Lopes, Macêdo, Menezes, 2016; Beuren, Machado, Vesco, 2015; Cardoso, Oyadomari, Mendonça Neto, 2007). Macêdo, Menezes, 2016; Beuren, Machado, Vesco, 2015; Cardoso, Oyadomari, Mendonça Neto, 2007).

According to Dantas, Silva, Santana, Vieira (2011), in order to analyze the evolution of a given area of knowledge, it is essential to disseminate the research esplanade, considering that only after the publication of research in the formal channels of scientific education does its result gain importance, which is the basic requirement for the dissemination and evolution of knowledge.

In this context, bibliometrics is one of the most used methods for the analysis of scientific production, mainly aiming at obtaining indicators from the different areas of knowledge in which it is applied. Bibliometric studies are generally characterized as quantitative, as they aim to catalog, classify, and quantify the knowledge about a given theme (Pedroni, Guerrazzi, Serra, Albanese, 2016). They can also be conceptualized as a part of science that, through the investigation of scientific publications, aims to list the main characteristics of the researched scientific communication (Souza; Silva; Araújo, 2013).

Bibliometrics has been consolidated over the years as a technique with high potential for appreciation and measurement of several research themes, through which it is possible to carry out relevant mappings on several areas of knowledge, such as the study by Porte and Sampaio (2014), which discusses auditing and used more than 2,300 articles to survey results and build indicators. From this considerably large number of productions, it was possible to extract several diagnoses and valuable findings through the application of bibliometric tools.

Scientific productions in the Brazilian academy have been adding to the bibliometric approaches the studies on collections of magazines, thus evaluating the full or partial production of these content bases, such as the studies of Francisco (2011), Ribeiro (2012), Corrêa, Ruiz and Ribeiro (2013), Ribeiro (2013), Beuren, Machado and Vesco (2015), Abdalla et al. (2014), Ribeiro e Silva (2016) and Favaretto and Francisco (2017). These approaches analyzed several bibliometric indicators, some of the most common, are listed below with the authorship assignments duly specified:

(i) authors with the largest number of publications (all authors mentioned above applied this indicator);

(ii) institutions with more publications in the magazine (Francisco, 2011; Ribeiro, 2012; Ribeiro, 2013; Ruiz and Ribeiro, 2013; Abdalla et al. 2014; Corrêa, Ribeiro e Silva, 2016);

(iii) main topics covered (Francisco, 2011; Corrêa, Ruiz and Ribeiro, 2013; Ribeiro, 2013; Beuren, Machado and Vesco, 2015);

(iv) number of authors per article (Francisco, 2011; Ribeiro, 2012; Corrêa, Ruiz and Ribeiro, 2013; Ribeiro, 2013; Ribeiro e Silva, 2016);

(v) keywords most cited in publications (Francisco, 2011; Ribeiro, 2012; Corrêa, Ruiz and Ribeiro, 2013; Ribeiro, 2013; Favaretto and Francisco, 2017).

\section{Procedimentos Metodológicos}


Once the general objective of this study was defined, in order to fulfill it, it was decided to choose a representative sample among the Brazilian journals with better qualification.

According to ANPCONT (2020) there are eight Brazilian journals and institutions linked to them with better classification among journals in the accounting area. They are at QUALIS A2 level, as shown in Chart 1.

Chart 1: Brazilian accounting journals QUALIS A2

\begin{tabular}{|ll|}
\hline Magazine - Akroniem & Institution \\
Advances in Scientific and Applied Accounting - ASAA & \\
Brazilian Business Review - BBR & ANPCONT \\
Contabilidade Vista \& Revista - CVR & FUCAPE/ES \\
Revista Brasileira de Gestão de Negócios- RBGN & UFMG/MG \\
Revista Contabilidade \& Finanças - RCF & FECAP/SP \\
Revista Contemporânea de Contabilidade - RCC & FEA/USP/SP \\
Revista de Contabilidade e Organizações - RCO & UFSC/SC \\
Revista Universo Contábil - RUC & FEA/USP/RP \\
\hline
\end{tabular}

Source: ANPCONT

Chart 1 finds that in relation to the institutions linked to the journals, five are public, two (UFMG and UFSC) federal, two state (USP/SP and USP/RP) and one municipal (FURB), two are private (FUCAPE and FECAP) and one is not linked to the educational institution, but to an association. In terms of geographic location, four of them are from the State of São Paulo (ANPCONT, FECAP, USP/SP and USP/RP), two from Santa Catarina (UFSC and FURB), one from Espírito Santo (FUCAPE) and one from Minas Gerais (UFMG).

It was decided, then, for the purpose of the research, to choose two of the eight journals to make up the representative sample of $25 \%$ of the total. To minimize possible bias, we chose to choose journals of different administrative categories and geographic location. These guidelines led to the choice of Vista \& Revista Accounting - CVR of the Federal University of Minas Gerais and the Brazilian Journal of Management and Business - RBGN of FECAP São Paulo.

We chose to adopt a long period to carry out the research, between the years 2010 and 2020, raising all publications of articles in the area of tax accounting in each of the journals, year by year, in order to observe possible changes over time. The consultation of the published articles in the editions of the selected journals were carried out through the virtual addresses of each of them.

Taking into account that the descriptive research is based on the registration and analysis to reach relevant data about a phenomenon, such as: nature, characteristic and correlations (Cervo and Bervian, 2002), it can be said that the present research has descriptive character when caring for such aspects. Therefore, to proceed through a scientific analysis, this work was based on a database composed of a set of published articles, using bibliometrics for its correlation.

Bibliometrics can be defined as a descriptive analysis with quantitative treatment of the characteristics of recorded information, being subject to the application of several methods that aim at the same objective. According to Lopes Piñero (1972), bibliometrics, as a statistical and sociometric analysis of scientific literature, 
aims, first, to analyze the size (extension), growth and distribution of the bibliography, followed by the study of the social structure of the groups that produce and use it the scientific literature.

After choosing the period to be analyzed and the journals to be used for the composition of the population, it was followed to define the study sample. As occurred for the choice of journals and publication period, we used the intentional non-probabilistic sampling technique consisting of a selected sampling type that seeks only to study the required data, aiming to have more representative data of the object of study.

For this purpose, search tools available on the websites of the journals were used, in which the words searched could be anywhere in the article (title, abstract, keywords or development). The words searched were: "tributária" and "tax".

After defining the sample, it was possible to apply a bibliometric study, in which, through the aid of an Excel spreadsheet, the collected data, referring to the population and sample, were grouped in such a way as to make up Table 1, as shown below.

The columns represent the analyzed period from 2010 to 2020. However, for better visualization and understanding of the table, only the final numbers of each year were used so that they could be arranged in only one table.

For cases in which there were no published articles on the proposed theme "Tax Accounting", as is the case for the year 2012 and 2014, no articles were analyzed, and they were not considered in the calculations performed.

Table 1: Composition of population and sample

\begin{tabular}{ccccccccccccc}
\cline { 2 - 5 } & $\mathbf{1 0}$ & $\mathbf{1 1}$ & $\mathbf{1 2}$ & $\mathbf{1 3}$ & $\mathbf{1 4}$ & $\mathbf{1 5}$ & $\mathbf{1 6}$ & $\mathbf{1 7}$ & $\mathbf{1 8}$ & $\mathbf{1 9}$ & $\mathbf{2 0}$ & Total \\
Population & $\mathbf{4 8}$ & $\mathbf{4 8}$ & $\mathbf{4 8}$ & $\mathbf{5 2}$ & $\mathbf{5 0}$ & $\mathbf{5 8}$ & $\mathbf{5 0}$ & $\mathbf{5 0}$ & $\mathbf{5 0}$ & $\mathbf{6 6}$ & $\mathbf{5 3}$ & $\mathbf{5 7 3}$ \\
CVR & 24 & 24 & 24 & 20 & 18 & 18 & 18 & 18 & 18 & 18 & 15 & 215 \\
RBGN & 24 & 24 & 24 & 32 & 32 & 40 & 32 & 32 & 32 & 48 & 38 & 358 \\
Sample & 1 & $\mathbf{1}$ & $\mathbf{0}$ & $\mathbf{1}$ & $\mathbf{0}$ & $\mathbf{4}$ & $\mathbf{4}$ & $\mathbf{3}$ & $\mathbf{5}$ & $\mathbf{4}$ & $\mathbf{2}$ & $\mathbf{2}$ \\
CVR & $\mathbf{0}$ & $\mathbf{0}$ & $\mathbf{0}$ & $\mathbf{0}$ & $\mathbf{0}$ & 2 & 1 & 1 & 3 & 3 & $\mathbf{0}$ & 10 \\
RBGN & 1 & 1 & 0 & 1 & $\mathbf{0}$ & 2 & 3 & 2 & 2 & 1 & 2 & 15 \\
\hline
\end{tabular}

Source: Authors

In table 1, it is possible to observe that among the 573 articles published between 2010 and 2020, 215 articles are from CVR and 358 are from RBGN. From this population, a sample composed of 25 articles dealing with Tax Accounting was selected, 10 from CVR and 15 from RBGN.

It can also be seen based on Table 1, that the number of articles in 2020 was lower when compared to the immediately preceding years. This is due to the present study being conducted during the second half of 2020 and did not include articles that could eventually be published at the end of the second half of 2020 .

Table 2 shows the frequency of the sample in relation to the population, that is, the annual frequency in which articles on Tax Accounting were published in relation to the total number of articles submitted. 
Contabilidade tributária: Estudo bibliométrico da área contábil entre o período de 2010 a 2020.

Table 2: Frequency of tax accounting per year in the journals analyzed

\begin{tabular}{cccc} 
Year & $\begin{array}{c}\text { Total of Articles } \\
\text { Published }\end{array}$ & $\begin{array}{c}\text { Total articles on "Tax } \\
\text { Accounting" }\end{array}$ & Frequency (\%) \\
2010 & 48 & 1 & $2 \%$ \\
2012 & 48 & 1 & $2 \%$ \\
2012 & 48 & 0 & $0 \%$ \\
2013 & 52 & 1 & $2 \%$ \\
2014 & 50 & 0 & $0 \%$ \\
2015 & 58 & 4 & $7 \%$ \\
2016 & 50 & 4 & $8 \%$ \\
2017 & 50 & 3 & $6 \%$ \\
2018 & 50 & 5 & $10 \%$ \\
2019 & 65 & 4 & $8 \%$ \\
2020 & 53 & 2 & $4 \%$ \\
Total & 572 & 25 & $5 \%$ \\
\hline
\end{tabular}

Source: Authors

Table 2 shows that in the full period of the research the production of articles on tax accounting accounted for $5 \%$ of the publications in the journals examined and that from 2015 the participation is increasing with the apex in 2018, when it was $10 \%$.

Given the data collected and tabulated, it was possible to conduct an investigation in order to study the scientific production of the topic addressed. For that, the sample articles that resulted in the main results described in the next section were analyzed.

\section{Main Results}

Through the specific objectives defined, it was possible to visualize how scientific production on Tax Accounting at CVR and RBGN is characterized between the years 2010 and 2020 in several aspects.

The first specific objective seeks to identify which line of research is predominantly used in the sample articles, theoretical or empirical. It is important to highlight that the theoretical definition used for the analysis made consists of the concepts defined by Demo (2000), in which he affirms that the theoretical research has as its main characteristic "to reconstruct theory, concepts, ideas, ideologies, controversies, taking into account seen, in immediate terms, to improve theoretical foundations ", while, according to him, empirical research deals with the" empirical and factual face of reality; produces and analyzes data, always proceeding through empirical and factual control ". Thus, the articles of the two journals on Tax Accounting, between 2010 and 2020, were considered, showing how the lines of research were composed, segregating them between these two types in Table 3. 
Marcelo Rabelo Henrique, Jéssica Medeiros da Silva, Antônio Saporito \& Sandro Braz Silva.

\begin{tabular}{cccc} 
& \multicolumn{1}{c}{ Table 3: Classification of Articles by Type of Research } \\
\cline { 2 - 4 } Search Type & CVR & RBGN & Total \\
Theoretical & 0 & 1 & 1 \\
Empirical & 10 & 14 & 24 \\
Total & 10 & 15 & 25
\end{tabular}

Source: Authors

Through this table, it is possible to infer that the authors who discussed Tax Accounting, in the period addressed, have a preference for empirical rather than theoretical research, and only $1 / 25$ of the publications in the sample present as a predominant characteristic the desire to deepen theoretical foundations. It is concluded, therefore, that the analyzed theme of this work is more addressed through empirical research, because it corresponds to the intentions of the authors when researching on this theme.

In order to meet the second specific objective, to analyze how many authors published between 2010 and 2020 in the CVR and RBGN journals, table 4 was constructed.

Table 4: Number of Authors of Publications on Tax Accounting

\begin{tabular}{lccccc}
\hline Publications & \multicolumn{5}{c}{ Number of Authors per Sample Article } \\
& One & Two & Three & Four & Total \\
CVR & 1 & 3 & 5 & 1 & 10 \\
RBGN & 0 & 9 & 3 & 3 & 15 \\
Total & 1 & 12 & 8 & 5 & 25 \\
\hline
\end{tabular}

Source: Authors

It is interesting to note, through table 4, that of the articles that make up the sample, only one has a single authorship and there is a maximum of four authors. Also, it is noticed that in the journal CVR most of the articles have three authors, while the RBGN has the majority of the sample articles prepared by two authors. Given that the number of articles in the RBGN is higher, in general almost half of the articles have two authors.

To fulfill the third specific objective of identification of the authors, two tables and a table were created. Table 2 reports the names of all authors of the 25 articles in the sample, separated by journal and together. 
Chart 2. Authors of articles by journal and in a consolidated manner

\begin{tabular}{|c|c|c|}
\hline Authors RBGN - Alphabetical Order & Authors CVR - Alphabetical Order & Authors General - Alphabetical Order \\
\hline 1 Adriano Rodrigues & 1 Alexandre Castro Ribeiro & 1 Adriano Rodrigues \\
\hline 2 Aldy Fernandes da Silva & 2 Alexandre Gonzales & 2 Aldy Fernandes da Silva \\
\hline 3 Antonio Gledson de Carvalho & 3 Alvaro Augusto Ricardino Filho & 3 Alexandre Castro Ribeiro \\
\hline 4 Arilton Teixeira & 4 Antônio Cezar Bornia & 4 Alexandre Gonzales \\
\hline 5 Carlos Alberto Diehl & 5 Antonio Lopo Martinez & 5 Alvaro Augusto Ricardino Filho \\
\hline 6 Carlos Osmar Berter & 6 Antonio Lopo Martinez & 6 Antônio Cezar Bornia \\
\hline 7 Carlos Patricio Samanez (in memory) & 7 Bruno Funchal & 7 Antonio Gledson de Carvalho \\
\hline 8 Clóvis Antônio Kronbauer & 8 Carlos Henrique Silva do Carmo & 8 Antonio Lopo Martinez \\
\hline 9 David Eduardo Lopez Pantoja & 9 Caroline Sulzbach Pletsch & 9 Antonio Lopo Martinez \\
\hline 10 Ézio C. S. Baptista & 10 Clarice Gutierrez Kitamura Kajimoto & 10 Arilton Teixeira \\
\hline 11 Fábio Henrique Ferreira de Albuquerque & 11 Cristian Bau Dal Magro & 11 Bruno Funchal \\
\hline 12 Felipe Tumenas Marques & 12 Daniela Aparecida Vuolo & 12 Carlos Alberto Diehl \\
\hline 13 Fernando Alberto Dutra Fernandes & 13 Elizete Aparecida de Magalhães Wakim & 13 Carlos Henrique Silva do Carmo \\
\hline 14 Fernando Lucena Aiube & 14 Jacir Leonir Casagrande & 14 Carlos Osmar Berter \\
\hline 15 Gustavo Rique Pinto Passos & 15 João Eustáquio de Lima & 15 Carlos Patricio Samanez (in memory) \\
\hline 16 Itsaso Barrainkua & 16 Lara Fabiana Dallabona & 16 Caroline Sulzbach Pletsch \\
\hline 17 Javier Gutiérrez Castro & 17 Leonardo Bittencourt Ronconi & 17 Clarice Gutierrez Kitamura Kajimoto \\
\hline 18 Jorge Barros & 18 Marco Antonio Figueiredo Milani Filho & 18 Clóvis Antônio Kronbauer \\
\hline 19 José Luiz dos Santos & 19 Maria Denize Henrique Casagrande & 19 Cristian Bau Dal Magro \\
\hline 20 Julija Cassiano Neves & 20 Michele Rílany Rodrigues Machado & 20 Daniela Aparecida Vuolo \\
\hline 21 Leonardo Pinheiro Deboçã & 21 Pedro José Von Mecheln & 21 David Eduardo Lopez Pantoja \\
\hline 22 Leonel Cesarino Pessôa & 22 Ricardo Sartori Cella & 22 Elizete Aparecida de Magalhães Wakim \\
\hline 23 Lucimar Antônio Cabral de Ávila & 23 Sílvio Hiroshi Nakao & 23 Ézio C. S. Baptista \\
\hline 24 Luiz Henrique Figueira Marquezan & 24 Thiago Bruno de Jesus Silva & 24 Fábio Henrique Ferreira de Albuquerque \\
\hline 25 Marcela Espinosa Pike & 25 Vasconcelos Reis Wakim & 25 Felipe Tumenas Marques \\
\hline 26 Marcello Muniz da Silva & 26 Vinicius Costa da Silva Zonatto & 26 Fernando Alberto Dutra Fernandes \\
\hline 27 Marcelo Alvaro da Silva Macedo & & 27 Fernando Lucena Aiube \\
\hline 28 Marco Aurélio Gomes Barbosa & & 28 Gustavo Rique Pinto Passos \\
\hline 29 Marcos Reinaldo Severino Peters & & 29 Itsaso Barrainkua \\
\hline 30 Mauro Fernando Gallo & & 30 Jacir Leonir Casagrande \\
\hline 31 Milton de Abreu Campanário & & 31 Javier Gutiérrez Castro \\
\hline 32 Paulo Schmidt & & 32 João Eustáquio de Lima \\
\hline 33 Ricardo Silveira Martins & & 33 Jorge Barros \\
\hline 34 Roberto Carlos Klann & & 34 José Luiz dos Santos \\
\hline 35 Rodrigo da Silva Santos Curvello & & 35 Julija Cassiano Neves \\
\hline 36 Sady Mazzion & & 36 Lara Fabiana Dallabona \\
\hline 37 Silvia Marcia Russi De Domenico & & 37 Leonardo Bittencourt Ronconi \\
\hline 38 Sueli dos Santos Leitão & & 38 Leonardo Pinheiro Deboçã \\
\hline 39 Tiago Cardão-Pito & & 39 Leonel Cesarino Pessôa \\
\hline & & 40 Lucimar Antônio Cabral de Ávila \\
\hline & & 41 Luiz Henrique Figueira Marquezan \\
\hline & & 42 Marcela Espinosa Pike \\
\hline & & 43 Marcello Muniz da Silva \\
\hline & & 44 Marcelo Alvaro da Silva Macedo \\
\hline & & 45 Marco Antonio Figueiredo Milani Filho \\
\hline & & 46 Marco Aurélio Gomes Barbosa \\
\hline & & 47 Marcos Reinaldo Severino Peters \\
\hline & & 48 Maria Denize Henrique Casagrande \\
\hline & & 49 Mauro Fernando Gallo \\
\hline & & 50 Michele Rílany Rodrigues Machado \\
\hline & & 51 Milton de Abreu Campanário \\
\hline & & 52 Paulo Schmidt \\
\hline & & 53 Pedro José Von Mecheln \\
\hline & & 54 Ricardo Sartori Cella \\
\hline & & 55 Ricardo Silveira Martins \\
\hline & & 56 Roberto Carlos Klann \\
\hline & & 57 Rodrigo da Silva Santos Curvello \\
\hline & & 58 Sady Mazzion \\
\hline & & 59 Silvia Marcia Russi De Domenico \\
\hline & & 60 Sílvio Hiroshi Nakao \\
\hline & & 61 Sueli dos Santos Leitão \\
\hline & & 62 Thiago Bruno de Jesus Silva \\
\hline & & 63 Tiago Cardão-Pito \\
\hline & & 64 Vasconcelos Reis Wakim \\
\hline & & 65 Vinicius Costa da Silva Zonatto \\
\hline
\end{tabular}

Source: authors based on their magazine websites 
From chart 2, the 65 authors of the 25 articles used are identified, and only one author, Antonio Loppo Martinez, is the author of two articles. The other 63 authors contributed only one article each. It is in doubt, then, that there is no group of authors that, from a quantitative point of view, stand out. The number of authors in RBGN articles is higher than in the CVR in the same proportion as the number of articles.

Table 5 shows the highest titles of each of the 65 authors, and if one of the authors holds a degree, master's and doctorate degrees, it will only be considered the doctor, because it is the largest title among the others, thus aiming to facilitate the interpretation of the data. Considering this classification, the table below presents the academic degree of the authors for each journal analyzed.

Table 5: Distribution of Authors' Titles in the Sample

\begin{tabular}{|c|c|c|c|c|}
\hline Titles & Papers CVR & Papers RBGN & Total & $\%$ \\
\hline Graduated / Graduating & 1 & 0 & 1 & $2 \%$ \\
\hline Master science & 5 & 9 & 14 & $22 \%$ \\
\hline $\mathrm{PhD}$ & 20 & 28 & 48 & $74 \%$ \\
\hline Pos-Phd & - & 2 & 2 & $3 \%$ \\
\hline Total & 26 & 39 & 65 & $100 \%$ \\
\hline
\end{tabular}

Source: Authors

Table 5 shows that most authors who write about tax accounting are doctors, a total of 48 out of 65 . This observation is also true when considering each of the journals in isolation. The authors with a master's degree in a total of 14 is the second most important group and the group formed by the sum of doctors and masters, in number of 62 , accounts for $96 \%$ of the authors.

For the identification of the authors, table 6 was also created, in which the information about the authors was worked in order to understand the relationship between the publications and the University of the authors' education by regions of Brazil, as provided below.

Table 6: Distribution of Regions of Authors' Universities

\begin{tabular}{|c|c|c|c|}
\hline $\begin{array}{c}\text { Regions of Authors' } \\
\text { Universities }\end{array}$ & Articles CVR & Articles RBGN & $\begin{array}{c}\text { Total of Authors' } \\
\text { Universities by } \\
\text { Region }\end{array}$ \\
\hline
\end{tabular}

$\begin{array}{lcccc}\text { Northern } & 0 & 0 & 0 & 0 \% \\ \text { Northeast } & 0 & 0 & 0 & 0 \% \\ \text { Midwest } & 3 & 0 & 3 & 4 \% \\ \text { Southeast } & 16 & 22 & 38 & 54 \% \\ \text { South } & 10 & 6 & 16 & 23 \% \\ \text { Out of Brazil } & 3 & 11 & 14 & 20 \%\end{array}$


Contabilidade tributária: Estudo bibliométrico da área contábil entre o período de 2010 a 2020.
Total
32
39
71
$100 \%$

Source: Authors

Through table 6, it is possible to note the relationship between the journals in which the articles in the sample were published and the Universities in which the authors are affiliated. Thus, it is perceived that most of the authors of the articles published in the journals belong to the Southeast region, about $54 \%$, followed by the South region with $23 \%$, and approximately $20 \%$ is represented by teaching universities outside the country. It is possible to note that the North and Northeast regions do not have contributions in the journals analyzed in the area of tax accounting.

To address the fourth specific objective defined, we analyzed the references used by each article in the sample, segregating them into eight categories, in order to analyze what types of documents the authors use to write their research on tax accounting. The eight categories defined were: article, dissertation, legislation, book, thesis, text for discussion, accounting standards and others.

In table 7, it is possible to identify for each journal what type of document predominates as a reference used for the preparation of the component articles of the sample used. It is considered a predominant document in the preparation of the article, the type of document that was the most used in relation to the other eight types in each of the articles.

\begin{tabular}{|c|c|c|c|c|}
\hline Type & CVR & RBGN & Total & \%Total \\
\hline Article & 11 & 15 & 26 & $100 \%$ \\
\hline Dissertation & 0 & 0 & 0 & $0 \%$ \\
\hline Legislation & 0 & 0 & 0 & $0 \%$ \\
\hline Book & 0 & 0 & 0 & $0 \%$ \\
\hline Thesis & 0 & 0 & 0 & $0 \%$ \\
\hline Discussion text & 0 & 0 & 0 & $0 \%$ \\
\hline Accounting standards & 0 & 0 & 0 & $0 \%$ \\
\hline Other & 0 & 0 & 0 & $0 \%$ \\
\hline Total & 11 & 15 & 26 & $100 \%$ \\
\hline
\end{tabular}

Source: Authors

Thus, it is possible to identify how the references used by the authors are segregated. It is possible to notice similar behavior between the two journals and that the use of articles as the main type of reference in the elaboration of all the component works of the sample predominated.

\section{Considerations}

In this research, the general objective was to verify how the scientific production on tax accounting is characterized in two journals, CVR and RBGN, between 2010 and 2020. To achieve this goal, articles published in these journals were collected, forming a population of 573 studies, of which only 25 deal with Tax Accounting corresponding to $5 \%$ of the total. 
For the analysis of this sample composed of 25 scientific articles, we used the bibliometric study defining six specific objectives that led this research, being possible through them, to reach the following conclusions: (i) the vast majority of the articles are empirical in nature, representing more than $95 \%$ of the sample; (ii) there was only one article publication by a single author and none with more than four authors, the most common being to have two authors per publication; (iii) authors with an academic degree of $\mathrm{PhD}$, as the highest title, were the ones who contributed the most to research and authors who have been based in universities in the Southeast region account for more than half of the publications; (iv) In the references used by the authors there is a marked preference mainly for articles.

Through this research, it was possible to obtain characteristics of publications on tax accounting and through a small sample of articles published with this theme, infer several relevant information. In order to add to the scientific production, about this branch that is infrequent in relation to the research of the accounting area, this article was developed, seeking a greater contribution in this field of research.

For future studies, it is suggested to expand the number of journals, maintaining the analyzed period, so that a more representative sample of the reality of scientific production on tax accounting in Brazil can be observed and it can be observed whether or not the results converge with those presented here. Another possibility and keep the journals and period, changing the area of research.

\section{Referências}

Abdalla, K. G. M. Z., Rocha, D. T., Cruz, J. A. W., Santos, F. L. X. D., Andrich, R. G., \& Tardelli, M. (2014). Pensando Contabilidade: um estudo bibliométrico e sociométrico da produção científica da Revista Pensar Contábil no Período 2006-2012. Pensar Contábil, 16(59), 30-38.

Almeida, L. F. C., Machado, M. R. R., Machado, L. S., \& Zanolla, E. (2017). Análise Bibliométrica da Produção Científica Brasileira em Contabilidade Tributária. Contexto - Revista do Programa de Pós-Graduação em Controladoria e Contabilidade da UFRGS, 17(35), 36-54.

Anjos, C. E. L. D., Pederneiras, M. M. M., Lopes, J. E. G., Macêdo, J. M. A., \& Menezes, D. C. C. L. (2016). Mercado de capitais como foco das pesquisas em contabilidade: um estudo bibliométrico da produção científica nacional. Contexto - Revista do Programa de Pós-Graduação em Controladoria e Contabilidade da UFRGS, 16(33), 128-145.

Anpcont. Periódicos de Contabilidade. Disponível em <http://anpcont.org.br/periodicos-de-contabilidade>. Acesso em: 15 de junho de 2020

Araújo, C. A. (2006). Bibliometria: evolução histórica e questões atuais. Em Questão, Porto Alegre, v. 12, n. 1, p. 11 - 32.

Beuren, I. M., Machado, D. G., \& Vesco, D. G. D. (2015). Análise Sociométrica e Bibliométrica de Pesquisas Publicadas no Management Accounting Research. Contabilidade, Gestão e Governança, 18(1), 83-105.

Borges, H. B. (2002). Planejamento Tributário. São Paulo: Atlas.

Carneiro, J. D. (Coord.). (2008). Proposta nacional de conteúdo para o curso de graduação em Ciências Contábeis. Brasília: Fundação Brasileira de Contabilidade.

Cardoso, R. L., Oyadomari, J. C., \& Mendonça Neto, O. R. (2007). Influências da Positive Accounting nos Programas de Mestrado em Contabilidade: uma análise bibliométrica da produção acadêmica. Brazilian Business Review, 4(2), 158-170.

Cervo, a. L. Bervian, P. A. (2002). Metodologia científica. 5.ed. São Paulo: Prentice Hall.

Contabilidade Vista \& Revista. Disponível em: < https://revistas.face.ufmg.br/index.php/contabilidadevistaerevista/issue/archive>. Acesso em 05/08/2020.

Corrêa, R., Ruiz, M. S., \& Ribeiro, H. C. M. (2013). The international journal of conflicts management: uma análise da produção acadêmica à luz da bibliometria de 2003 a 2012. Reunir: Revista de Administração, Contabilidade e Sustentabilidade, 3(4), 1-19.

Da Silva, L. T. (2019). Planejamento Tributário:. REGRAD - Revista Eletrônica de Graduação do UNIVEM - ISSN 1984-7866, [S.I.], v. 12, n. 01, p. 110 - 128, nov. ISSN 1984-7866. Disponível em: <https://200.10.239.72/REGRAD/article/view/2843>. Acesso em: 10 oct. 2020 
Dantas, J. $\quad$ A., $\quad$ Silva, $\quad$ C. $\quad$ T., $\quad$ Santana, $\quad$ C. $\quad$ M., $\quad$ Vieira, $\quad$ E. $\quad$ T. (2011). Padrões de comunicação científica em contabilidade: um comparativo entre a Revista Contabilidade e Finanças e a The Accounting Review. Revista Contemporânea de Contabilidade, Florianópolis, v. 8, n. 16, p. 11- 36.

Demo, P. (2000). Introdução ao ensino da metodologia da ciência. São Paulo: Atlas.

Eloy, J. A. C. C., Soares, S. V., Casagrande, M. D. H. (2014). A Produção Cientifica Brasileira Sobre Contabilidade Tributária em Periódicos e Eventos no Período de 1989-2011. Revista de Contabilidade e Controladoria, v. 6, n.1, p. 89-102.

Fabretti, L. C. (2006). Contabilidade tributária. 10 ed. São Paulo: Atlas.

Fabretti, L. C. (2009). Contabilidade Tributária. 11. ed. São Paulo: Atlas.

Favaretto, J. E. R., \& Francisco, E. R. (2017). Exploração do Acervo da RAE-Revista de Administração de Empresas (de 1961 a 2016 ) à Luz da Bibliometria, Text Mining, Rede Social e Geoanálise. Revista de Administração de Empresas, 57(4), 365-390.

Formigoni, H. (2008). A influência dos incentivos fiscais sobre a estrutura de capital e a rentabilidade das companhias abertas brasileiras não financeiras. Tese (Doutorado em Controladoria e Contabilidade: Contabilidade) - Faculdade de Economia, Administração e Contabilidade, Universidade de São Paulo, São Paulo, 2008. doi:10.11606/T.12.2008.tde-13012009-155610. Acesso em: 2020-10-10.

Francisco, E. R. (2011). RAE-eletrônica: exploração do acervo à luz da bibliometria, geoanálise e redes sociais. Revista de Administração de Empresas, 51(3), 280- 306.

ludícius, S., Martins, E., Gelbcke, E. R. (2007). Manual de contabilidade das sociedades por ações: aplicável às demais Sociedades. 7. ed. São Paulo: Atlas.

Higuchi, H. Higuchi, C. H. (2005). Imposto de renda das empresas: interpretação e prática. 30.ed. São Paulo: Atlas.

Lima (1986). R. C. M. de. Bibliometria: análise quantitativa da literatura como instrumento de administração em sistemas de informação. Ci. Inf., Brasília, 15 (2): 127-33, jul/dez.

Lima, F. B. Duarte, A. M. P. (2007). Planejamento Tributário: Instrumento Empresarial de Estratégia Competitiva. Qualitos Revista Eletrônica - ISSN 1677-4280. v 6. N1. Disponível em: <http://revista.uepb.edu.br/index.php/qualitas/article/viewFile/106/75>. Acesso em: 15 de abril de 2019.

Monteiro, J. E. R., Silva, G. I. S., Peter, M. G. A., Machado, M. V. V. (2011). Ética e Contabilidade: Estudo Bibliométrico das Publicações dos Anais do Enanpad Na Primeira Década do Século XXI. In: XIV Seminários de Administração. Disponível em: <http://sistema.semead.com.br/14semead/resultado/trabalhosPDF/1015.pdf>. Acesso em: 01 Junho 2019.

Neves, S., Viceconti, P. E. V. (2017). Contabilidade Básica. 17 ed. rev. e atual. São Paulo: Saraiva.

Oliveira, L. M., Chieregato, R., Perez Junior, J. H., Gomes, M. B. (2006). Manual de contabilidade tributária. 5. ed. São Paulo: Atlas.

Oliveira, L. M., - Perez Junior, J. H., - Chieregato, R., - Gomes, M. B. (2014). . Manual de Contabilidade Tributária. 13. ed. São Paulo: Atlas.

Paula, D. G. (2018). O Planejamento Tributário Como Instrumento de Competividade Empresarial; RFPTD - Revista de Finanças Públicas Tributação e Desenvolvimento - ISSN 2317-837X, . v. 6, n. 7, p. 16 - 32, jul-dez. Disponível em: < https://www.epublicacoes.uerj.br/index.php/rfptd/article/view/36587/26807>. Acesso em: 10 out. 2020.

Pedroni, F. V., Guerrazzi, L. A. C., Serra, F. A. R., Albanese, D. E. (2016). Investigación contable, un estudio bibliométrico: identificación de publicaciones relevantes y examen de la estructura intelectual. Revista Contemporânea de Contabilidade, Florianópolis, v.13, n. 53, p. $53-91$.

Porte, M. S., \& Sampaio, E. S. (2015). Pesquisa Bibliométrica e Cienciométrica em Auditoria (2002-2013). Revista de Educação e Pesquisa em Contabilidade, 9(2), 143-159.

Revista Brasileira de Gestão de Negócios. Disponível em: < https://rbgn.fecap.br/RBGN/issue/archive>. Acesso em 05/08/2020.

Rezende, A. J., Pereira, C. A., Alencar, R. C. (2010). Contabilidade Tributária: Entendendo a Lógica e seus Reflexos sobre os Resultados das Empresas. Edição $1^{\circ}$. São Paulo: Editora Atlas.

Ribeiro, H. C. M. (2012). Brazilian Business Review: Um estudo sob a ótica da bibliometria e da rede social de 2004 a 2011. Revista de Gestão, Finanças e Contabilidade, 2(3), 86-104.

Ribeiro, H. C. M. (2013). Avaliação da produção acadêmica da revista Gestão \& Regionalidade de 2005 a 2012 através de bibliometria e sociometria. Gestão e Sociedade, 7(18), 425-450.

Ribeiro, H. C. M. (2014). Quinze anos de produção acadêmica do tema Contabilidade Internacional: uma análise bibliométrica em periódicos brasileiros. Revista de Educação e Pesquisa em Contabilidade, 8(3), 326-343 
Ribeiro, H. C. M., \& Silva, M. C. (2016). Mapeando a produção acadêmica da revista ambiente contábil à luz da bibliometria e rede social de 2009 a 2014. Sinergia, 20(2), 89-102.

Roza, M. C., Machado, D. G., Quintana, A. C. (2011). Análise Bibliométrica da Produção Científica sobre Contabilidade Pública no Encontro de Administração Pública e Governança (EnAPG) e na Revista de Administração Pública (RAP), no Período $2004-2009$. ConTexto, Porto Alegre, vol. 11, n. 20, p. 59-72, $2^{\circ}$ semestre.

Soares, S. V., Richartz, F., Voss, B. L., Freitas, C. L. (2011). Evolução do currículo de contabilidade no Brasil desde 1809. Revista Catarinense da Ciência Contábil, v. 10, n. 30, p. 27-42.

Souza, F. J. V., Silva, M. C., Araújo, A. O. (2013). Uma análise da produção científica da área de contabilidade governamental nos periódicos que utilizam o SEER e o SCIELO. Revista de Contabilidade da UFBA, Salvador, v. 7, n. 2, p. 22- 37.

Theóphilo, C. R., Sacramento, C. O. J., Neves, I. F.; Souza, P. L. (2000). O ensino da teoria da contabilidade no Brasil. Contabilidade Vista \& Revista, v. 11, n. 3, p. 3-10, dez.

Zanluca, J. César. (2018). Planejamento Tributário - Luxo ou Necessidade?, Portal tributário <http://www.portaltributario.com.br/artigos/planejamento.htm>. Acesso em: 06 de novembro de 2018.

\section{DADOS DOS AUTORES}

\section{Marcelo Rabelo Henrique}

Doutor em Administração e Mestre em Ciências Contábeis

Professor da Universidade Federal de São Paulo - UNIFESP

Endereço: Rua Angélica, 100 - Jardim das Flores

CEP: 06110295 - Osasco, SP - Brasil

Email: mrhenique@unifesp.br

\section{Jéssica Medeiros da Silva}

Graduanda em Ciência Contábeis

Universidade Federal de São Paulo - UNIFESP

Endereço: Rua Angélica, 100 - Jardim das Flores

CEP: 06110295 - Osasco, SP - Brasil

E-mail: jessica.medeiros@unifesp.com

\section{Antonio Saporito}

Doutor em Ciências Contábeis e Mestre em Ciências Contábeis

Professor da Universidade Federal de São Paulo - UNIFESP

Endereço: Rua Angélica, 100 - Jardim das Flores

CEP: 06110295 - Osasco, SP - Brasil

Email: saporito@unifesp.br

\section{Sandro Braz Silva}

Doutor em Administração e Mestre em Ciências Contábeis

Professor da Universidade Federal de São Paulo - UNIFESP

Endereço: Rua Angélica, 100 - Jardim das Flores

CEP: 06110295 - Osasco, SP - Brasil

Email: sandro.braz@unifesp.br 
Contabilidade tributária: Estudo bibliométrico da área contábil entre o período de 2010 a 2020.

Contribuição dos Autores:

\begin{tabular}{|c|c|c|c|c|}
\hline Contribuição & $\begin{array}{c}\text { Marcelo } \\
\text { Rabelo } \\
\text { Henrique }\end{array}$ & $\begin{array}{c}\text { Jessica } \\
\text { Medeiros da } \\
\text { Silva }\end{array}$ & $\begin{array}{l}\text { Antonio } \\
\text { Saborito }\end{array}$ & $\begin{array}{l}\text { Sandro Braz } \\
\text { Silva }\end{array}$ \\
\hline 1. Concepção do assunto e tema da pesquisa & $\mathrm{x}$ & $x$ & & \\
\hline 2. Definição do problema de pesquisa & $x$ & $x$ & $x$ & $x$ \\
\hline $\begin{array}{l}\text { 3. Desenvolvimento das hipóteses e constructos da } \\
\text { pesquisa (trabalhos teórico-empíricos) }\end{array}$ & $\mathrm{x}$ & $X$ & $X$ & \\
\hline $\begin{array}{l}\text { 4. Desenvolvimento das proposições teóricas } \\
\text { (trabalhos teóricos os ensaios teóricos) }\end{array}$ & $\mathrm{X}$ & $\mathrm{x}$ & $\mathrm{x}$ & \\
\hline 5. Desenvolvimento da plataforma teórica & $\mathrm{X}$ & & $\mathrm{X}$ & \\
\hline 6. Delineamento dos procedimentos metodológicos & $\mathrm{x}$ & $\mathrm{X}$ & & \\
\hline 7. Processo de coleta de dados & & $x$ & & \\
\hline 8. Análises estatísticas & & $\mathrm{x}$ & $\mathrm{x}$ & $\mathrm{X}$ \\
\hline 9. Análises e interpretações dos dados coletados & $\mathrm{X}$ & $\mathrm{X}$ & $\mathrm{x}$ & \\
\hline 10. Considerações finais ou conclusões da pesquisa & $\mathrm{X}$ & $\mathrm{X}$ & $x$ & $x$ \\
\hline 11. Revisão crítica do manuscrito & $\mathrm{X}$ & & $\mathrm{x}$ & $\mathrm{x}$ \\
\hline 12. Redação do manuscrito & $\mathrm{x}$ & & & \\
\hline
\end{tabular}

